\title{
Nomenclature for "Micrococcus radiodurans" and Other Radiation-Resistant Cocci: Deinococcaceae fam. nov. and Deinococcus gen. nov., Including Five Species
}

\author{
B. W. BROOKS† AND R. G. E. MURRAY \\ Department of Microbiology and Immunology, University of Western Ontario, London, Ontario Canada, \\ N6A $5 C 1$
} \begin{abstract}
are as follows:

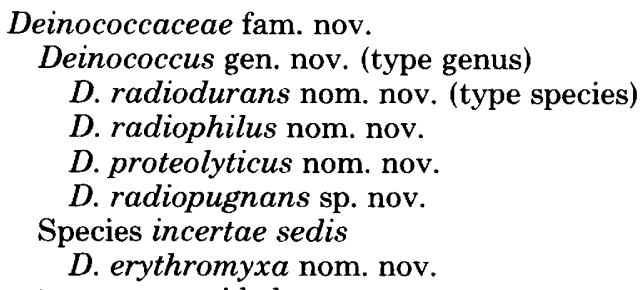

Descriptions of the taxa are provided.
\end{abstract}

The data assembled by Brooks et al. (Int. J. Syst. Bacteriol. 30:627-646, 1980) suggest that the radiation-resistant, red, gram-positive, tetrad-forming cocci exemplified by "Micrococcus radiodurans" (not on Approved Lists of Bacterial Names [Skerman et al., Int. J. System. Bacteriol. 30:225-420, 1980]) are a distinct natural group separate from Micrococcus. The nomenclature proposed here for these organisms utilizes specific epithets used in the original names of these organisms, which names were made illegitimate by omission from the Approved Lists. One species is added to those named before 1 January 1980. The proposals

"Micrococcus radiodurans" (19) (names in quotation marks were not included on the Approved Lists of Bacterial Names [21]) was the name given to a remarkable radiation-resistant coccus isolated by Anderson et al. (1) from irradiated meat. Most of the detailed studies of this organism have used the $R_{1}$ strain of Anderson et al. or the Sark strain (R. G. E. Murray and C. F. Robinow, Abstr. 7th Int. Congr. Microbiol., p. 427,1958 ), which was later shown to be closely related (5). Structural and biochemical analysis of the cell walls of these two strains showed distinct differences from Micrococcus species: a complex profile in sections $(15,22,25)$ and $\mathrm{L}$ ornithine with di- or triglycine as the interpeptide bridge in the peptidoglycan $(5,20,26)$. Furthermore, the predominant fatty acid in lipid extracts of these cells was a 16:1 component (5, 10,12 ), which is commonly associated with gram-negative bacteria.

Hill (11) aligned the radiation-resistant, redpigmented, catalase-positive micrococci with other similarly pigmented, gram-positive organisms such as Micrococcus roseus and M. agilis. Subsequent taxonomic analysis by Baird-Parker

$\dagger$ Present address: Department of Veterinary Microbiology, University of Guelph, Guelph, Ontario, Canada.
$(2,3)$ suggested that these strains should be excluded from the genus Micrococcus because of the nature of the cell wall $(20,27)$ and lipid (12) constituents in addition to radiation resistance. These strains, under the common name "Micrococcus radiodurans," were placed in Bergey's Manual (4) in the incertae sedis section appended to Micrococcus for determinative purposes. The recent taxonomic study by Feltham (9) also suggests that " $M$. radiodurans" and its relatives are distinct from conventional Micrococcus species. This distinction has been confirmed by Brooks et al. (5), with additional evidence supporting and amplifying the earlier recognition by Davis et al. (8), Lewis (17), and Kobatake et al. (13) of distinctive organisms within the radiation-resistant group. Recent structural observations on these organisms (15, $22,23)$ emphasize the unique features of their cell walls and membranes. The application of ribosomal ribonucleic acid oligonucleotide sequence catalog data provides the best evidence in support of the thesis that these organisms are unrelated or are very distantly related to Micrococcus (5).

The situation is made the more complex because the name " $M$. radiodurans," as well as " $M$. radiophilus" (17) and " $M$. radioproteolyti- 
cus" (13), which may be considered relatives, were omitted from the Approved Lists of Bacterial Names (21). Therefore, it is the intent of this paper to establish a nomenclature and appropriate descriptions of the taxa to provide a legitimate basis for referring to these organisms and to stimulate studies of this unique group. No disrespect is intended toward the original authors of the specific epithets proposed in this paper; the provisions of the Bacteriological Code (1976 revision) do not allow their inclusion as contributions to new combinations of names.

The taxonomic treatment put forward in this paper is based on the comparative data published by Brooks et al. (5) and on their more detailed studies of representative strains of the apparent phenotypic clusters. It is clear that the red-pigmented micrococci, $M$. roseus and $M$. agilis, are species of Micrococcus Cohn 1872 (14) and are quite separate from the radiationresistant " $M$. radiodurans" (Table 1) and the organisms that resemble it. Therefore, we hereby conserve the elegant and effective specific epithet "radiodurans" associated with this organism (19) in the new name Deinococcus radiodurans. The new generic name Deinococcus implies that these cocci have remarkable properties. The appropriate descriptions follow.

Description of the type strain of $D$. $r a$ diodurans nom. nov. M.L. adj. ra.di.o. du'rans. L.n. radiatio radiation; L. part. adj. durans enduring; radiodurans resisting radiation.

Spheres, 1.5 to $3 \mu \mathrm{m}$ in diameter, occurring singly and in pairs and dividing in two planes to form tetrads or tablets of cells. Nonmotile.

The peptide subunit of the cell wall contains L-alanine, D-glutamic acid, and L-ornithine. The interpeptide bridge contains glycine. Teichoic acids are absent. The cell wall consists of at least four layers and has a total thickness of 130 to $140 \mathrm{~nm}$. The peptidoglycan-containing layer is fenestrated. The outermost layer consists of hexagonally packed protein subunits.

The predominant fatty acid component is palmitoleate. No branched-chain fatty acids are present.

Colonies are red, smooth, and convex with a regular edge. Multiple carotenoids are present.

Chemoorganotrophic; metabolism is strictly respiratory. Acid production from some carbohydrates (glucose and fructose) is variable. Fructose, glycerol, glucose, and mannose are utilized, but no acid is produced in standard broth.

Strictly aerobic. Optimal growth temperature is $30^{\circ} \mathrm{C}$. All strains grow in the presence of $1 \%$ $\mathrm{NaCl}$ and most grow in $5 \% \mathrm{NaCl}$ in media. Nitrates are not reduced to nitrites.
Resistant to $1.5 \mathrm{Mrad}$ of gamma radiation and exposure to $1,800 \mathrm{ergs} / \mathrm{cm}^{2}$ per $\mathrm{s}$ of ultraviolet radiation for $10 \mathrm{~min}$.

Guanine-plus-cytosine $(\mathrm{G}+\mathrm{C})$ content of the deoxyribonucleic acid (DNA) is $67 \mathrm{~mol} \%$ (by $\left.T_{m}\right)$.

Type strain: ATCC (American Type Culture Collection) 13939 (=UWO [Collection in the Department of Microbiology and Immunology, University of Western Ontario] 288).

Variations in cell wall structure, reduction of nitrates, tolerance to sodium chloride, proportion of fatty acid components, and loss of pigmentation have been observed in strains included in $D$. radiodurans. Some greater variations among strains assigned to $D$. radiodurans e.g., strains $1083, \mathrm{G}+\mathrm{C}=70 \mathrm{~mol} \%$; see Table 2) will demand detailed study in the future in terms of relatedness and species assignment of the strains.

Description of Deinococcus gen. nov. Dei no . coc'cus. Gr. adj. deinos strange or unusual; Gr. n. coccus a grain or berry; M.L. masc. n. Deinococcus unusual coccus.

Cells spherical, 0.5 to $3.5 \mu \mathrm{m}$ in diameter, occurring singly and in pairs and dividing in two planes to form tetrads or tablets of cells. Nonmotile. No resting stages known. Gram positive.

Chemoorganotrophic; metabolism is respiratory. Glucose may be metabolized, but acid is produced from only a limited number of carbohydrate substrates, if at all. Catalase is produced. Carotenoid pigments usually are present, and colonies are usually pink to brick red.

Aerobic. Optimal growth temperature is 25 to $35^{\circ} \mathrm{C}$.

Several distinct cell wall layers are visible in thin sections, and the walls may contain lipoprotein. The interpeptide bridge of the peptidoglycan contains glycine, and the peptide subunit contains L-alanine, D-glutamic acid, and L-ornithine. Teichoic acids are absent.

Many strains are resistant to $1.5 \mathrm{Mrad}$ of gamma radiation and to exposure to $1,800 \mathrm{ergs} /$ $\mathrm{cm}^{2}$ per $\mathrm{s}$ of ultraviolet radiation for $10 \mathrm{~min}$.

The fatty acid component palmitoleate accounts for at least $25 \%$ of the total fatty acid composition.

The $\mathrm{G}+\mathrm{C}$ content of the DNA ranges from 62 to $70 \mathrm{~mol} \%$ (by $T_{m}$ ).

Type species: Deinococcus radiodurans.

Family relationship of the genus Deinococcus. Results of comparative cataloging of $16 \mathrm{~S}$ ribosomal ribonucleic acid taken together with the results of DNA homology, the analysis of fatty acid composition, and the analysis of cell wall structure and composition indicate a very distant relationship between $D$. radiodurans 


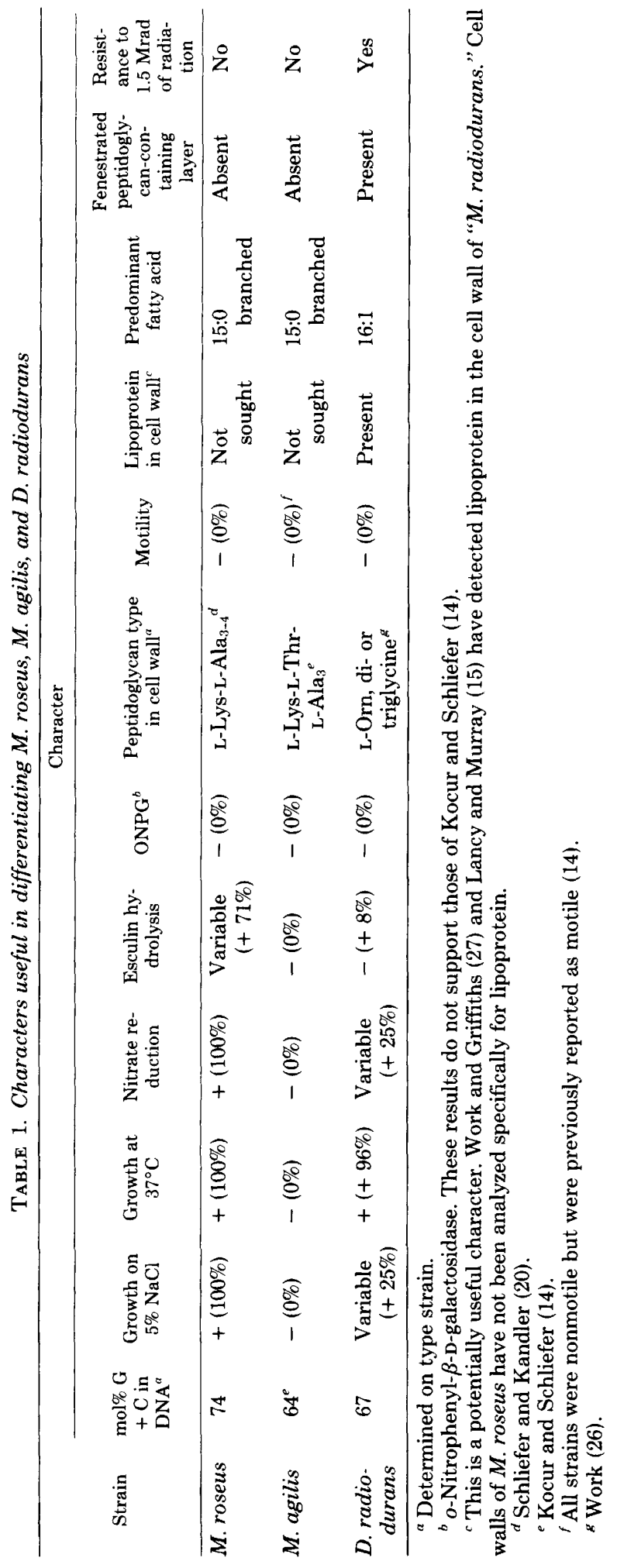


TABLE 2. Differential characters of miscellaneous strains of red-pigmented cocci

\begin{tabular}{|c|c|c|c|c|c|c|c|c|c|}
\hline \multirow[b]{2}{*}{ Strain } & \multicolumn{9}{|c|}{ Character } \\
\hline & $\begin{array}{l}\text { Nitrate } \\
\text { reduc- } \\
\text { tion }\end{array}$ & $\begin{array}{l}\text { Acid } \\
\text { from } \\
\text { glucose } \\
\text { in } \\
\text { stand- } \\
\text { ard me- } \\
\text { dium }\end{array}$ & $\begin{array}{c}\operatorname{mol} \% \mathrm{G} \\
+\mathrm{C} \text { in } \\
\text { DNA }\end{array}$ & $\begin{array}{l}\text { Resist- } \\
\text { ance to } \\
\text { gamma } \\
\text { radiation }\end{array}$ & $\begin{array}{l}\text { Cell size } \\
\quad(\mu \mathrm{m})\end{array}$ & $\begin{array}{l}\text { Peptidoglycan } \\
\text { type in cell wall }\end{array}$ & $\begin{array}{c}\text { Growth in } \\
\text { presence } \\
\text { of } 5 \% \\
\mathrm{NaCl}\end{array}$ & $\begin{array}{l}\text { Predomi- } \\
\text { nant fatty } \\
\text { acid }\end{array}$ & $\begin{array}{l}\text { Branched- } \\
\text { chain fatty } \\
\text { acid }\end{array}$ \\
\hline $\begin{array}{l}\text { D. radiophilus } \\
\text { UWO } 1055\end{array}$ & - & - & 62 & $\mathrm{Yes}^{a}$ & $1.0-2.0$ & $\mathrm{~L}-\mathrm{Orn}-\mathrm{Gly}_{2}{ }^{b}$ & + & $16: 1$ & $\begin{array}{l}\text { Not de- } \\
\text { tected }\end{array}$ \\
\hline $\begin{array}{l}\text { D. proteolyticus } \\
\text { UWO } 1056\end{array}$ & - & + & 65 & $\mathrm{Yes}^{c}$ & $1.0-2.0$ & $\mathrm{~L}$-Orn-Gly ${ }^{b}$ & - & $16: 1$ & $\begin{array}{l}\text { Not de- } \\
\text { tected }\end{array}$ \\
\hline $\begin{array}{l}\text { D. radiopugnans } \\
\text { UWO } 293\end{array}$ & + & - & 70 & Yes $^{d}$ & $1.0-2.0$ & Orn-Gly ${ }_{2}$ & - & $16: 1,17: 0$ & $15: 0$ \\
\hline $\begin{array}{l}\text { D. erythromyxa } \\
\text { UWO } 1045\end{array}$ & + & - & 71 & $\mathrm{Yes}^{e}$ & $1.0-2.5$ & L-Lys-L-Ala ${ }_{3-4}{ }^{\prime}$ & + & $16: 0,18: 1$ & $\begin{array}{l}\text { Not pres- } \\
\text { ent }\end{array}$ \\
\hline $\begin{array}{l}\text { D. radiodurans } \\
\text { UWO } 1083\end{array}$ & + & - & 70 & $\mathrm{Yes}^{g}$ & $1.5-3.0$ & $\mathrm{Orn}_{-\mathrm{Gly}_{2}}$ & - & $15: 1,16: 1$ & $\begin{array}{l}\text { Not pres- } \\
\text { ent }\end{array}$ \\
\hline
\end{tabular}

${ }^{a}$ Lewis (17).

${ }^{b}$ Sleytr et al. (23).

c Kobatake et al. (13).

${ }^{d}$ Davis et al. (8).

${ }^{e} D_{10}=0.127$ to 0.254 Mrad (R. G. E. Murray, D. G. Storey, and J. L. Whitby, unpublished data).

$f$ Schliefer and Kandler (20).

${ }^{g}$ E. A. Christensen, Statens Seruminstitut, Copenhagen, Denmark, personal communication.

and $M$. roseus (5). For these multiple reasons, we believe that these organisms should not be assigned to the same family.

In the eighth edition of Bergey's Manual (6), three families (Micrococcaceae, Streptococcaceae, and Peptococcaceae) are included in part 14, Gram-Positive Cocci. The inclusion of $D$. radiodurans in any of these three families is not appropriate. Therefore, Deinococcaceae fam. nov. is proposed with Deinococcus as the type genus. For determinative reasons ("gram-positive cocci" being a convenient assembly) and until strong phylogenetic or other data demand some other alignments, this new family should remain in Part 14 of Bergey's Manual, or its equivalent.

Description of the family Deinococcaceae fam. nov. Dei-no·coc·ca'ce·ae. M.L. masc. n. Deinococcus type genus of the family; -aceae ending to denote family; M.L. fem. pl. n. Deinococcaceae the Deinococcus family.

Cells spherical, 0.5 to $3.5 \mu \mathrm{m}$ in diameter, characteristically dividing in more than one plane to form tetrads or tablets. Nonmotile. Resting stages are not produced. Gram positive.

Chemoorganotrophic; metabolism is respiratory. Acid without gas is produced from glucose, when attacked.

Nutritional requirements are variable.

Catalase positive.

Aerobic.

The fatty acid component palmitoleate accounts for at least $25 \%$ of the fatty acid composition.
Several distinct cell wall layers are visible in thin section, and the cell wall contains lipoprotein. L-Ornithine is present in the peptide subunit of the peptidoglycan; exceptions may occur.

Many strains are resistant to high levels of gamma and ultraviolet radiation.

The $\mathrm{G}+\mathrm{C}$ content of the DNA ranges from 62 to $70 \mathrm{~mol} \%$ (by $T_{m}$ ).

Type genus: Deinococcus.

Taxonomic status of other radiation-resistant, red-pigmented strains. On the basis of fatty acid composition, in terms of both components detected and relative percentage of individual components, Brooks et al. (5) distinguished eight strains (formerly known as $M$. roseus UWO 293, M. roseus UWO 294, " $M$. radiophilus" UWO 1055, " $M$. radioproteolyticus" UWO 1056, $M$. roseus UWO 1045, $M$. roseus UWO 1088, “ $M$. radiodurans" UWO 1083 , and " $M$. radiodurans" UWO 1085) from $M$. roseus, $M$. agilis, and " $M$. radiodurans" (now $D$. radiodurans). At the same time, the fatty acid compositions and the analyses of the cell wall profiles of these eight strains indicate that these organisms can be divided into five clusters (Table 2). The strains formerly known as " $M$. radiophilus" (UWO 1055) and "M. radioproteolyticus" (UWO 1056) were distinct from each other and from the other six strains. $M$. roseus strains UWO 293 and 294 were similar to each other, as were $M$. roseus strains UWO 1045 and UWO 1088 and " $M$. radiodurans" strains UWO 1083 and UWO 1085.

Determination of cell wall profiles and of fatty 
acid composition has provided differential characters for taxonomic purposes at the level of family or genus, but these are of limited value for species identification. Unfortunately, the chemistry of the cell walls of the eight strains, beyond establishing the peptidoglycan type, has not been studied in detail.

Taxonomic status of the organism formerly known as "M. radiophilus." The organism formerly known as " $M$. radiophilus" UWO 1055 was isolated by Lewis (17), who described it as a new species which differed from " $M$. radiodurans" in size, tolerance to sodium chloride, and degree of resistance to gamma radiation. No type strain was designated, but Lewis described only a single strain (ATCC 27603); according to Rule $18 \mathrm{c}$ of the Bacteriological Code (16), this strain must be accepted as the type. The name Deinococcus radiophilus nom. nov. is proposed for this organism.

Description of the type strain of $D$. radiophilus nom. nov. Ra.di-o'phil.us. M.L. n. radiatio radiation; Gr. adj. philos loving; M.L. adj. radiophilus radiation loving.

Spheres, 1.0 to $2.0 \mu \mathrm{m}$ in diameter, occurring singly and in pairs and dividing in two planes to form tetrads. Nonmotile.

The peptide subunit of the cell wall contains L-ornithine, and the interpeptide bridge contains glycine. The cell wall consists of at least three distinct layers.

The predominant fatty acid component is palmitoleate. No branched-chain fatty acids are present.

Colonies are orange-red, smooth, and convex with a regular edge. Multiple carotenoids are present.

Chemoorganotrophic; metabolism is strictly respiratory. No acid is produced in standard broth containing glucose or fructose.

Strictly aerobic. Optimal growth temperature is $30^{\circ} \mathrm{C}$. Grows in the presence of $5 \% \mathrm{NaCl}$. Nitrates are not reduced to nitrates. Catalase positive.

Resistant to $1.5 \mathrm{Mrad}$ of gamma radiation.

$\mathrm{G}+\mathrm{C}$ content of the DNA is $62 \mathrm{~mol} \%$ (by $T_{m}$ ).

Type strain: ATCC 27603 (= UWO 1055).

Taxonomic status of the organism formerly known as " $M$. radioproteolyticus." " $M$. radioproteolyticus" was isolated by Kobatake et al. (13) and was described as a new species. No type strain was designated, but because only a single strain was described (Czechoslovak Collection of Microorganisms [CCM] strain 2703), it is the type strain by monotypy (Rule 18c). The specific epithet is illegitimate (Rule 12a) because it expresses more than a single concept. Kobatake et al. (13) recognized that this organism was more active in digesting proteins (milk, soya, and gelatin) than was " $M$. radiodurans" and expressed this in forming the epithet. We retain this approach.

Brooks et al. (5) and Sleytr et al. (23) reported additional characters for this organism: the fatty acid composition of this strain and the cell wall profile are similar to those of $D$. radiodurans and $D$. radiophilus. Acid production from glucose and fructose in the standard medium, nonspecific esterase banding patterns, and results from studies on DNA homology support the recognition of this organism as a separate species. The name Deinococcus proteolyticus nom. nov. is proposed for this organism.

Description of the type strain of $D$. pro-

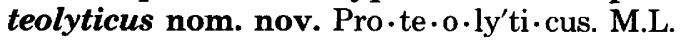
m. adj. proteolyticus proteolytic.

Spheres, 1.0 to $2.0 \mu \mathrm{m}$ in diameter, occurring singly and in pairs and dividing in two planes to form tetrads. Nonmotile.

The peptide subunit of the cell wall contains $\mathbf{L}$-ornithine, and the interpeptide bridge contains glycine. The cell wall consists of at least three distinct layers.

The predominant fatty acid component is palmitoleate. No branched-chain fatty acids are present.

Colonies are orange-red, smooth, and convex with a regular edge. Multiple carotenoids are present.

Chemoorganotrophic; metabolism is respiratory. Acid but no gas is produced from glucose and fructose in standard broth. Milk is peptonized and gelatin is liquefied.

Strictly aerobic. Optimal growth temperature is $30^{\circ} \mathrm{C}$. Grows in the presence of $1 \% \mathrm{NaCl}$. Nitrates are not reduced to nitrates. Catalase positive.

Resistant to 1.5 Mrad of gamma radiation. $\mathrm{G}+\mathrm{C}$ content of the DNA is $65 \mathrm{~mol} \%$ (by $T_{m}$ ). Type strain: CCM 2703 (= UWO 1056).

Taxonomic status of the organism formerly known as the "Davis" or "haddock" strain of $M$. roseus. In 1964, Davis et al. (8) reported the isolation of a radiation-resistant coccus from haddock tissue (UWO 293). It was distinguished from " $M$. radiodurans" by size, nitrate reduction, and gelatin hydrolysis. Davis et al. did not identify their isolate, but Girard (10) studied it and included it with $M$. roseus despite the findings of Davis et al. It is evident from the study of Brooks et al. (5) that the Davis strain is a member of neither $M$. roseus nor the genus Micrococcus.

The fatty acid composition of the Davis isolate is distinct from that of $D$. radiodurans in terms of the components and, in particular, their rela- 
tive proportions. A 15:0 branched-chain fatty acid, not detected in $D$. radiodurans, is present in the Davis isolate. The profile of the cell wall of the Davis isolate consists of at least three distinct layers and is thus similar to that observed in $D$. radiophilus and $D$. proteolyticus. This information as well as DNA homology data (5) supports the recognition of this isolate as a distinct species. Deinococcus radiopugnans is suggested as an appropriate name for this organism, and UWO 293 is proposed as the type strain.

Description of the type strain of $D$. radi-

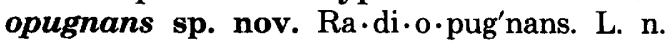
radiatio radiation; L. part. adj. pugnans fighting or resisting; M.L. adj. radiopugnans radiation resisting.

Spheres, 1.0 to $2.0 \mu \mathrm{m}$ in diameter, occurring singly and in pairs and dividing in two planes to form tetrads or tablets of cells. Nonmotile.

The cell wall consists of at least three layers, and the peptidoglycan-containing layer is fenestrated.

Two fatty acid components, palmitoleate and heptadecanoate, present in approximately equal proportion, together account for at least $50 \%$ of the total fatty acid composition. A 15-carbon, branched-chain, saturated fatty acid component is present.

Colonies are orange-red, smooth, and convex with a regular edge. Multiple carotenoids are present.

Chemoorganotrophic; metabolism is strictly respiratory. No acid is produced from glucose in standard medium. Catalase positive.

Strictly aerobic. Optimal growth temperature is $30^{\circ} \mathrm{C}$.

Grows in the presence of $1 \% \mathrm{NaCl}$. Nitrate is reduced to nitrite.

Resistant to $1.5 \mathrm{Mrad}$ of gamma radiation.

$\mathrm{G}+\mathrm{C}$ content of the DNA is $\mathrm{mol} \%$ (by $T_{m}$ ).

Type strain: ATCC 19172 (= UWO 293).

Smooth and rough variants, as well as variants with less pigment, may occur. The 15-carbon, saturated, branched-chain fatty acid component may be absent.

Taxonomic status of strains formerly identified as members of $M$. roseus (UWO 1045 and UWO 1088). $M$. roseus strains UWO 1045 and 1088 have similar cell wall profiles and fatty acid compositions but differ in both respects from the type strain of $M$. roseus, ATCC 186. On the basis of these two complex characters and DNA homology (5), M. roseus strain UWO 1045 is recognized as belonging to a species separate from $M$. roseus. Because $M$. roseus UWO 1045 was formerly called "Sarcina erythromyxa" (7), the name Deinococcus erythromyxa is suggested. The type strain of $D$. ery- thromyxa is ATCC 187 (= UWO 1045). Strain UWO 1088 will have to be left out of consideration for this taxon because repeated assessment of its peptidoglycan constitution reveals the presence of $m$-diaminopimelic acid and no trace of either ornithine or lysine (E. Stackebrandt, Technische Universität, Munich, West Germany, personal communication). However, in other respects the phenotypes of these two organisms, including the fatty acid constituents, are remarkably similar (5).

Description of the type strain of $D$. erythromyxa nom. nov. E.ry-thro-my'xa. Gr. adj. erythros red; Gr. n. myxa slime or mucus; M.L. n. erythromyxa red slime.

Spheres, 1.0 to $2.0 \mu \mathrm{m}$ in diameter, occurring singly and in pairs and dividing in two planes to form tetrads. Nonmotile.

The cell wall consists of two layers. The peptidoglycan is of the L-Lys-L-Ala ${ }_{3-4}$ type. The peptidoglycan-containing layer is not fenestrated.

Two fatty acid components, palmitate and oleate, are present in approximately equal proportion and together account for at least $60 \%$ of the total fatty acid composition. No branchedchain fatty acids are present.

Colonies are red, smooth, and convex with a regular edge. Multiple carotenoids are present.

Chemoorganotrophic; metabolism is strictly respiratory. No acid is produced from glucose in standard medium. Catalase positive.

Aerobic. Optimal growth temperature is $30^{\circ} \mathrm{C}$. Grows in the presence of $5 \% \mathrm{NaCl}$. Nitrates are reduced to nitrites.

Resistant to gamma radiation; the level is uncertain, but it is in the region of $1 \mathrm{Mrad}$.

$\mathrm{G}+\mathrm{C}$ content of the DNA is $71 \mathrm{~mol} \%$ (by $T_{m}$ ). Type strain: ATCC (= UWO 1045).

Intrageneric relationship of $D$. radiophilus, $D$. proteolyticus, $D$. radiopugnans, and D. erythromyxa. D. radiophilus, D. proteolyticus, and $D$. radiopugnans have complex cell walls with several obvious layers and a fatty acid component, palmitoleate, which accounts for at least $25 \%$ of the total fatty acid composition. All three strains have features characteristic of the genus Deinococcus; they are resistant to 1.5 Mrad of gamma radiation and have a peptidoglycan of the L-Orn-Gly 2 type.

However, results of DNA homology studies (5) between $D$. radiodurans UWO 298 and $D$. radiophilus, D. proteolyticus, and D. radiopugnans indicate only low homologies $(4,10$, and $12 \%$, respectively). Similarly, results of DNA homology studies between $D$. radiopugnans and $D$. radiodurans UWO $298, D$. radiophilis, and D. proteolyticus also indicate low homologies 
(17, 4, and $8 \%$, respectively). Results of comparative cataloging of $16 \mathrm{~S}$ ribosomal ribonucleic acid (5) indicate that there are 320 common bases between $D$. radiodurans UWO 298 and $D$. radiopugnans, which indicates that these two strains are related.

This information indicates that $D$. radiophi. lus, $D$. proteolyticus, and $D$. radiopugnans should be aligned with the genus Deinococcus. However, the low DNA homology values and the small number of positive characters used for description make it likely that some or all of these will have to be reassessed as members of the genus Deinococcus at some time in the future.

The generic relationship of D. erythromyxa is difficult to assess, because there is limited information suggesting distinction from both Micrococcus and Deinococcus. The cell wall profile is distinct from those of strains included in $M$. roseus, but the cell wall of $D$. erythromyxa does not have as many obvious layers as are seen in other species included in the genus Deinococcus. The peptidoglycan of $D$. erythromyxa is of the L-Lys-L-Ala ${ }_{3-4}$ type found in $M$. roseus strains. However, the fatty acid profiles of $M$. roseus (type strain) and D. erythromyxa are distinctly different. We find that the resistance of strains to gamma radiation is different but overlapping (M. roseus UWO 1057, type strain, $D_{10}=0.075$ to $0.157 \mathrm{Mrad}$; D. erythromyxa UWO $1045, D_{10}$ $=0.127$ to $0.254 \mathrm{Mrad}$, according to unpublished data of R. G. E. Murray, D. G. Storey, and J. L. Whitby). Unfortunately, there are no homology data or comparative cataloging of $16 \mathrm{~S}$ ribosomal ribonucleic acid of $M$. roseus and $D$. erythromyxa strains available. So, in the absence of a more appropriate niche, the species $D$. erythromyxa is included in the genus Deinococcus as a species incertae sedis awaiting further study and a more informed assignment. We can hope for a bigger collection of anomalous strains for a comparative study.

Regarding radiation resistance. It is worth noting that there is little consistency in the methods applied to determining radiation resistance and providing an effective comparison of organisms in this regard. Until some effective approach to comparable data is agreed upon, we are not prepared to provide figures that are different from those expressed in the literature. Our preliminary data (unpublished) confirm that all of the organisms selected as representative strains of Deinococcus species are remarkably resistant to gamma radiation and show a range of $D_{10}$ values of 0.100 to $0.547 \mathrm{Mrad}$, which probably corresponds to a sterilizing dose $\left({ }^{60} \mathrm{Co}\right.$; in air) approximating six times those values.
However, the values vary by as much as 20 to $100 \%$ according to the method used, notably cells dried on glass versus cells dried on a paper strip.

Radiation resistance is an attractive and selective character but, as discussed in the previous publication (5), it is mutable (13) and may not serve to distinguish all the near or distant relatives of this unusual family of bacteria.

(This paper derives in part from a thesis submitted by B. W. B. to the University of Western Ontario in partial fulfillment of the requirements for the M.Sc. degree.)

We are grateful for continuing support by the Medical Research Council of Canada.

We acknowledge the advice of D. E. Gerber, Department of Classical Studies, University of Western Ontario concerning an appropriate generic name. We are particularly appreciative of the assistance of J. L. Whitby and D. G. Storey in determining radiation sensitivity, E. Stackebrandt for the typification of peptidoglycan, and $\mathbf{E}$. Lessel for nomenclatural advice.

\section{REPRINT REQUESTS}

Address reprint requests to : Dr. R. G. E. Murray, Department of Microbiology and Immunology, University of Western Ontario, London, Ontario, N6A 5C1, Canada.

\section{LITERATURE CITED}

1. Anderson, A. W., H. C. Nordan, R. F. Cain, G. Parrish, and D. Duggan. 1956. Studies on a radio-resistant micrococcus. I. The isolation, morphology, cultural characteristics and resistance to gamma radiation. Food Technol. 10:575-577.

2. Baird-Parker, A. C. 1963. A classification of micrococci and staphylococci based on physiological and biochemical tests. J. Gen. Microbiol. 38:363-387.

3. Baird-Parker, A. C. 1970. The relationship of cell wall composition to the current classification of staphylococci and micrococci. Int. J. Syst. Bacteriol. 20:483-490.

4. Baird-Parker, A. C. 1974. Part 14, Gram-positive cocci, family I Micrococcaceae, p. 478-489. In R. E. Buchanan and N. E. Gibbons (ed.), Bergey's manual of determinative bacteriology, 8th ed. The Williams \& Wilkins Co., Baltimore.

5. Brooks, B. W., R. G. E. Murray, J. L. Johnson, E. Stackebrandt, C. R. Woese, and G. E. Fox. 1980. Red-pigmented micrococci: a basis for taxonomy. Int. J. Syst. Bacteriol. 30:627-646.

6. Buchanan, R. E., and N. E. Gibbons (ed.). 1974. Bergey's manual of determinative bacteriology, 8 th ed. The Williams \& Wilkins Co., Baltimore.

7. Chester, F. D. 1901. A manual of determinative bacteriology. The MacMillan Co., New York.

8. Davis, N. S., G. J. Silverman, and E. B. Masurovsky. 1963. Radiation-resistant, pigmented coccus isolated from haddock tissue. J. Bacteriol. 86:294-298.

9. Feltham, R. K. A. 1979. A taxonomic study of the Micrococcaceae. J. Appl. Bacteriol. 47:243-254.

10. Girard, A. E. 1971. A comparative study of the fatty acids of some micrococci. Can. J. Microbiol. 17:1503-1508.

11. Hill, L. R. 1959. The Adansonian classification of the staphylococci. J. Gen. Microbiol. 20:277-283.

12. Knivett, V. A., J. Cullen, and M. J. Jackson. 1965. Odd numbered fatty acids in Micrococcus radiodurans. Biochem. J. 96:2c-3c.

13. Kobatake, M., S. Tamabe, and S. Hasegawa. 1973. Nouveau micrococcus radioresistant à pigment rouge, isolé de feces de Lama glama, et son utilisation comme 
indicateur microbiologique de la radiosterilisation. $\mathrm{C}$. R. Soc. Biol. 167:1506-1510.

14. Kocur, M., and K. H. Schleifer. 1975. Taxonomic status of Micrococcus agilis Ali-Cohn 1889. Int. J. Syst. Bacteriol. 25:294-297.

15. Lancy, P., Jr., and R. G. E. Murray. 1978. The envelope of Micrococcus radiodurans: isolation, purification and preliminary analysis of the wall layers. Can. J. Microbiol. 24:162-176.

16. Lapage, S. P., P. H. A. Sneath, E. F. Lessel, V. B. D. Skerman, H. P. R. Seeliger, and W. A. Clark (ed.). 1975. International code of nomenclature of bacteria (bacteriological code, 1976 revision). American Society for Microbiology, Washington, D.C

17. Lewis, N. F. 1973. Radio-resistant Micrococcus radiophilus sp. nov. isolated from irradiated Bombay duck (Harpodon nehereus). Curr. Sci. 42:504.

18. Moseley, B. E. B. 1967. The isolation and some properties of radiation-sensitive mutants of Micrococcus radiodurans. J. Gen. Microbiol. 49:293-300.

19. Raj, H. D., F. L. Duryee, A. M. Deeney, C. H. Wang, A. W. Anderson, and P. R. Elliker. 1960. Utilization of carbohydrates and amino acids by Micrococcus radiodurans. Can. J. Microbiol. 6:289-298.

20. Schleifer, K. H., and O. Kandler. 1972. Peptidoglycan types of bacterial cell walls and their taxonomic implications. Bacteriol. Rev. 36:407-477.

21. Skerman, V. B. D., V. McGowan, and P. H. A. Sneath. 1980. Approved lists of bacterial names. Int. J. Syst. Bacteriol. 30:225-420.

22. Sleytr, U. B., M. Kocur, A. M. Glauert, and M. J. Thornley. 1973. A study by freeze-etching of the fine structure of Micrococcus radiodurans. Arch. Mikrobiol. 94:77-87.

23. Sleytr, U. B., M. T. Silva, M. Kocur, and N. F. Lewis. 1976. The fine structure of Micrococcus radiophilus and Micrococcus radioproteolyticus. Arch. Microbiol. 107:313-320.

24. Stackebrandt, E., and C. R. Woese. 1979. A phylogenetic dissection of the Family Micrococcaceae. Curr. Microbiol. 2:317-322.

25. Thornley, M. J., R. W. Horne, and A. M. Glauert. 1965. The fine structure of Micrococcus radiodurans. Arch. Mikrobiol. 51:267-289.

26. Work, E. 1970. The distribution of diamino acids in cell walls and its significance in bacterial taxonomy. Int. J. Syst. Bacteriol. 20:425-433.

27. Work, E., and H. Griffiths, 1968. Morphology and chemistry of cell walls of Micrococcus radiodurans. J. Bacteriol. 95:641-657. 